\title{
XXXVIII. On a new method of distinguishing arsenic from antimony, in cases of suspected poisoning by the former substance
}

\author{
Mr. J. Marsh
}

To cite this article: Mr. J. Marsh (1839) XXXVIII. On a new method of distinguishing arsenic from antimony, in cases of suspected poisoning by the former substance, Philosophical Magazine Series 3, 15:96, 282-284, DOI: 10.1080/14786443908649877

To link to this article: http://dx.doi.org/10.1080/14786443908649877

曲 Published online: 01 Jun 2009.

Submit your article to this journal $[\pi$

Џll Article views: 2

Q View related articles $\sqsubset$ 


\section{Mr. Marsh on distinguishing Arsenic from Antimony.}

of the scale, because there the cross strix lie much closer to each other. But if they are examined with more powerful instruments, and the forms adjusted so as to see the rising and sloping portion of the cross striæ, then instead of the diagonal line appearing, the ordinary longitudinal lines will appear "like short hairs or spines in a diagonal direction." In this way they appeared to Mr. Pritchard "through his best instruments." The varieties of appearance seem to me to arise from the instrument commanding at different times the different heights of an uneven surface, and the difference depends upon the distinct vision of the hill, the valley, or the intermediate slope, in a distance which between each longitudinal rib is only the $20,000 \mathrm{dth}$ of an inch. The cross striæ are about the $60,000 \mathrm{dth}$ of an inch apart, and near the end of the scale still less.

I remain, Gentlemen, yours, \&c.

Burton Latimer, Ang. 31, 1839.

Edward Craig.

Description of the Figures. (Plate $\mathrm{I}$.)

1. A section of the scales, showing the wavy nature of the ribbed surface.

2. A portion of the scale, showing only the longitudinal lines, and torn along one of the fibres.

3. A portion exhibiting the structure of the film, with the longitudinal and cross striæ.

4. A portion in which the dark longitudinal striæ are thrown out of the focus, and only the cross striæ shown.

5. A portion in which the delusive appearance of the diagonal lines is attempted to be imitated.

6. A portion in which the focus of the lens is so adjusted as to show only a portion of the cross striæ on the rising slope of the furrow.

XXXVIII. On a new Method of distinguishing Arsenic from Antimony, in cases of suspected poisoning by the former substance. By Mr. J. Marsh.*

I $\mathrm{N}$ testing for arsenic in cases of poisoning by that substance, it has always been desirable to render the process as simple as possible, and thereby divest the mind of any ambiguity on the subject. It was with this view that I submitted to the Society of Arts, \&c. in the year 1836, my process by hydrogen, a process that I then fondly hoped would have removed all difficulties; but a communication from my friend Mr. Lewis

* Communicated by the Author. 
Thompson, and which was inserted in the L. and E. Philosophical Magazine, vol.x. p. 353, has rendered the process in some measure more difficult than was at first supposed, by the discovery of that gentleman, of a compound in which antimony combines with hydrogen to form a gas (antimoniuretted hydrogen). 'This gas gives off' by the process employed, metallic crusts, which much resemble, to the inexperienced eye, the metallic substance obtained from arsenical solutions by the same arrangements. It becomes necessary therefore to find a means of distinguishing these metallic crusts from each other. Many processes which are well known to the experienced chenist may be employed for this purpose; but the misfortune is that all these arrangements suppose a previous chemical acquaintance with the sulject; for instance, a good process for this purpose is given by Liebig and Mohr in their valuable Journal (Lieb., Ann., xxiii. 217.) and also a modification of the same by Berzelius may be seen copied in the Lancet, vol. i. 1838 , p. 819 , but these are all liable to the above objection, viz. want of simplicity.

I am happy in being able to lay before your readers a very simple distinguishing test for these bodies, and which I have employed in all cases of doubt with perfect success. The means that I use is simply as follows: After the common arrangements have been made for testing for antimony or arsenic, the piece of glass or porcelain on which the metallic crusts are generally received; is to have a single drop of distilled water placed on it; the glass or porcelain is then to be inverted, so that the drop of water is suspended undermost. The gas as it issues from the jet is to be inflamed in the usual manner, but the piece of glass, \&c., with its drop of water, is to be held about an inch above the jet, or just above the apex of the cone of flame : the arsenic by this arrangement is oxidized at the same time that hydrogen is undergoing combustion, and coming in contact with the drop of water held above, forms with it a strong or weak solution of arsenical acid, according to the quantity of arsenic present, should that substance have been in the mixture subinitted to examination. A very minute drop of Hume's test (the ammoniacal nitrate of silver) being now dropped on the solution so obtained, if arsenic be present, the well-known characteristic lemon yellow colour produced by this test when used for testing for that substance is immediately produced, namely, the insoluble arsenite of oxide of silver. Antimony under these circumstances, from being insoluble, produces no change. I have found it useful, when much arsenic has been present in the matter submitted to examination, to use a clean glass tube, 6 inches long, and about 
284. Mr. Halliwell on Notices of America by Middle-ageWriters. $\frac{1}{2}$ an inch in diameter. I slightly moisten the interior of the tube with distilled water, not allowing the hands or fingers to come in contact with the water: the tube thus prepared is to be held vertically over the apex of the jet of burning gas. By these means a strong solution of the substance is obtained, and which may be tested with perfect ease by Hume's test, or any other of the usual tests employed for arsenic, \&c.

I hope that the foregoing process will be found to possess all the delicacy and precision necessary for distinguishing these two bodies from each other, and that it will be the means of removing every doubt from the minds of the experimentalist in future.

Royal Arsenal, Woolwich, June 21, 1839.

J. M.

XXXIX. An Account of a ferw Independent Notices of America by Middle-age Writers. By J. O. Halliwell, Esq., F.R.S., F.S.A., F.R.A.S., \&c.*

TN the notes to the new edition of the Travels of Sir John 1 Maundevile, I slightly noticed a very singular passage, which bears evidence of a far higher degree of geographical knowledge than the Englishmen of the fourteenth century have hitherto had credit for. I give it here at length in modern phraseology.

"In that land, nor in many others beyond, no man can see the star Transmontane, which is called the Star of the Sea, or Pole-Star; but men see another star, the contrary to it towards the south, and is called Antarctic. And this is because the world is of round shape, for the part of the firmament that shows in one country, does not show in another country. And men may well prove by experience and subtle trial of intellect, that if a man would search the world and find passage by ships, men might go by ships all about the world, both beneath and above. [He then gives his astronomical reasons, for which I refer to the work itself.] By the which I tell you certainly that men may environ all the earth, beneath and above, and return again to his own country, whoever had company and shipping, and alroays he roould find men, lands, isles, as well as in this country."

Maundevile afterwards proceeds to relate a story, which he had heard when young, of a traveller who from India got to Norway, and found several countries in his way. He also adds that there are more than five thousand islands beyond India, which shows that there was a very general notion of the extent of land in the western world.

- Communicated by the Author. 